\title{
"Health does not discuss trans bodies": Oral History of transsexuals and transvestites
}

\author{
"A saúde não discute corpos trans": História Oral de transexuais e travestis \\ "Salud no discute cuerpos trans": Historia Oral de transexuales y travestis
}

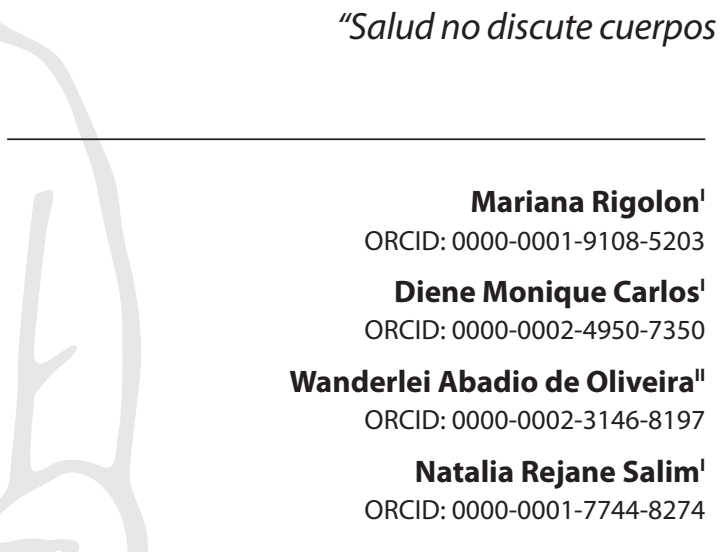

'Universidade Federal de São Carlos. São Carlos, São Paulo, Brazil.

"Pontifícia Universidade Católica de Campinas. Campinas, São Paulo, Brazil.

How to cite this article: Rigolon M, Carlos DM, Oliveira WA, Salim NR. "Health does not discuss trans bodies": Oral History of transsexuals and transvestites. Rev Bras Enferm. 2020;73(Suppl 6):e20190228. doi: http://dx.doi.org/10.1590/0034-7167-2019-0228

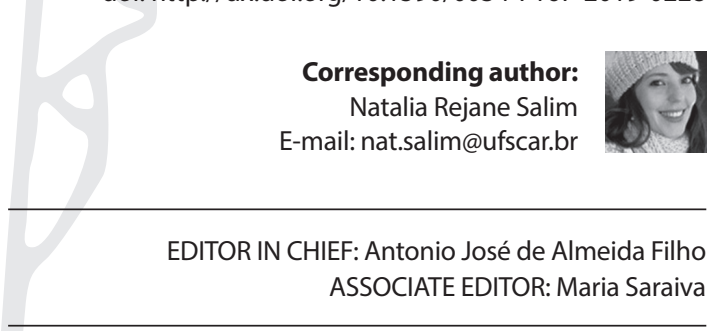

Submission: $06-18-2019$

Approval: $05-11-2020$

\begin{abstract}
Objectives: to understand the life stories and itineraries of transvestites and transsexuals in health services. Methods: study with a qualitative approach, anchored in the methodological framework of Oral History. Interviews were conducted and thematically analyzed. Results: two themes emerged: 1) gender and sexuality in life stories; and 2) the trajectories in health services. These revealed the challenges in the process of recognizing gender identity before the family and society. The reports show the dilemmas that transsexuals and transvestites face in health care, which ends up generating the removal of this population from services. Final Considerations: it has been demonstrated that Oral History can increase knowledge, especially about life histories and trajectories in the health services of transvestites and transsexuals; in addition, information was offered that can assist managers and health professionals in making decisions or caring for these people.
\end{abstract}

Descriptors: Transgender Persons; Gender Identity; Minority Health; Comprehensive Health Care; Public Health.

\section{RESUMO}

Objetivos: compreender as histórias de vida e o itinerário de travestis e transexuais nos serviços de saúde. Métodos: estudo de abordagem qualitativa, ancorada no referencial metodológico da História Oral. Foram realizadas entrevistas, sendo tematicamente analisadas. Resultados: emergiram dois temas: 1) gênero e sexualidade nas histórias de vida; e 2) as trajetórias nos serviços de saúde. Estes revelaram os desafios no processo de reconhecimento da identidade de gênero perante a família e sociedade. Os relatos mostram os dilemas que transexuais e travestis enfrentam no atendimento à saúde, o que acaba por gerar o afastamento dessa população dos serviços. Considerações Finais: demonstrou-se que a História Oral pode ampliar o conhecimento, especialmente, sobre as histórias de vida e trajetórias nos serviços de saúde de travestis e transexuais; além disso, foram oferecidas informações que podem auxiliar gestores e profissionais de saúde na tomada de decisão ou no cuidado em relação a essas pessoas.

Descritores: Pessoas Transgênero; Identidade de Gênero; Saúde das Minorias; Assistência Integral à Saúde; Sistema Único de Saúde.

\section{RESUMEN}

Objetivos: comprender las historias de vida y el itinerario de travestis y transexuales en los servicios de salud. Métodos: estudio de abordaje cualitativo, basado en el referencial metodológico de la Historia Oral. Han sido realizadas entrevistas, siendo temáticamente analizadas. Resultados: emergieron dos temas: 1) género y sexualidad en las historias de vida; y 2) las trayectorias en los servicios de salud. Estos revelaron los desafíos en el proceso de reconocimiento de la identidad de género delante la familia y sociedad. Los relatos muestran los dilemas que transexuales y travestis enfrentan en la atención a la salud, lo que acaba por generar el alejamiento de esa población de los servicios. Consideraciones Finales: se ha demostrado que la Historia Oral puede ampliar el conocimiento, especialmente, sobre las historias de vida y trayectorias en los servicios de salud de travestis y transexuales; además, han sido ofrecidas informaciones que pueden auxiliar gestores y profesionales de salud en la toma de decisión o en el cuidado en relación a esas personas.

Descriptores: Personas Transgénero; Identidad de Género; Salud de las Minorías; Asistencia Integral a la Salud; Sistema Único de Salud. 


\section{INTRODUCTION}

Transsexuality has long been considered a type of mental disorder linked to gender identity ${ }^{(1)}$. Only in 2018, in the 11 th edition of the International Statistical Classification of Diseases and Health Related Problems (ICD), published by the World Health Organization, that "sexual identity disorder" or "gender identity disorder" was no longer included in the classification and, therefore, to be seen as a pathology ${ }^{(2)}$. The debate was broadened, as well as the concept of gender, understood as something beyond biological sex, chromosomes or genitals, and constituted, mainly, by people's perception and social expression ${ }^{(3)}$.

According to the Yogyakarta Principles, gender identity is understood as the personal and individual experience in relation to each person's gender, which may or may not correspond to biological sex ${ }^{(3)}$. As a personal form of understanding the body, gender identity can include physical changes (whether or not involving surgical procedures) and in forms of gender expression, such as clothing and speech. The concept of "transgender" is a broad term that encompasses many gender identities and includes people who do not identify with biological sex; the term "cisgenerity" encompasses people who identify with the sex of birth.

However, this new understanding has not yet transformed the reality of people who come out as transsexuals and transvestites. They still go through processes of stigmatization that end up generating acts of violence and often even death ${ }^{(4-5)}$. In addition, these people are excluded from social life, from educational institutions, from the labor market and also from health services, and their rights as citizens are completely denied ${ }^{(4)}$.

This discrimination, based on gender identity or gender expression different from that defined at birth, is called "transphobia"(6). One of its consequences is the distancing of this population from health services, especially those offered by the Unified Health System (UHS), in the case of Brazil, and much of this distance is due to the lack of strategies that make these people's access easier and comfortable $^{(7)}$. They often self-medicate in order to avoid discrimination and prejudice to which they are exposed when they arrive at services where they will possibly be attended by professionals who have no knowledge of their specificities and needs ${ }^{(3)}$.

Despite advances in the sphere of their rights, the barriers encountered by transsexuals and transvestites to access the health system are multiple and multifactorial, going beyond discrimination, as verbal insults, often through more subtle processes, such as creating uncomfortable and deficient environments for the needs of these people ${ }^{(6)}$. It can be said that the lack of preparation of professionals is also related to not having any discipline on gender and sexuality or even discussions on the topic during their training, which leads to total ignorance and prejudiced, even violent, attitudes in transgender care ${ }^{(7)}$.

In the national scientific literature, the gap in fields such as nursing that discuss the health of transsexuals and transvestites is also notable. In this sense, it is recognized as essential the development of studies with the objective of subsidizing the assistance to these people, who go through different situations of social vulnerability and experience precarious solutions to deal with the physical and psychological suffering caused by dissatisfaction and strangeness with their bodies ${ }^{(8)}$.
In addition, scientific evidence has the possibility to assist health professionals in understanding these processes of vulnerability, which can amplify illnesses and, especially, suffering ${ }^{(9)}$. This population's access to the health system must also be facilitated by public policies, which lack evidence to organize themselves properly ${ }^{(10)}$.

\section{OBJECTIVES}

To understand the life stories and itineraries of transvestites and transsexuals in health services.

\section{METHODS}

\section{Ethical aspects}

The research was approved by the Research Ethics Committee (Opinion No. CAAE: 64169717.3.0000.5504.). Employees signed Free and Informed Consent Terms before the interviews.

\section{Type of study}

It is a qualitative research based on the methodological framework of Oral History, which allows access to the social experiences of people or groups. Oral History values excluded and marginalized social groups; and, through it, discriminated minorities are gaining space so that their voices, despised by other documents, can be heard and their experiences validated in opposition to the silencing experienced daily in society ${ }^{(11)}$. The COREQ script was used to report data collection.

\section{Methodological procedures}

\section{Study scenario}

The survey was conducted in a medium-sized city in the interior of the state of São Paulo, with approximately 220,000 inhabitants, with a demographic density of 195.15 hab. $/ \mathrm{km}^{2(12)}$.

\section{Data source}

The inclusion criteria for participation were: being a transsexual man or a transsexual or transvestite woman; be over 18 years old; and having experienced care in health services. Conversely, the exclusion criteria for participating in the research were: not having experience in attending health services; and being in a vulnerable situation that would prevent participation in the study. The snowball method was used to contact employees. The first participant was contacted during an academic event developed by an undergraduate nursing course at a federal university that discussed health and diversity issues.

Contact was made with five employees; one did not respond to the invitation. In total, four employees participated in this study, whose characterization is shown in Chart 1 . Their names were kept according to the methodology of Oral History, which values the identity of each of them and their will. Especially in relation to this theme, in which the name is a social achievement, it was decided to keep it through the consent and choice of the participants. 
Chart 1 - Characterization of participants according to age, education, professional performance and race

\begin{tabular}{|c|c|c|c|c|c|}
\hline Collaborator & $\begin{array}{c}\text { Gender } \\
\text { identity }\end{array}$ & Age & Education & Area & $\begin{array}{c}\text { Race/ } \\
\text { Ethnicity }\end{array}$ \\
\hline Erika & Transvestite & 23 & $\begin{array}{c}\text { Incomplete } \\
\text { higher } \\
\text { education }\end{array}$ & $\begin{array}{c}\text { Studying } \\
\text { Gerontology }\end{array}$ & Black \\
\hline Erianca & $\begin{array}{c}\text { Transsexual } \\
\text { Woman }\end{array}$ & 18 & $\begin{array}{c}\text { Complete } \\
\text { high school }\end{array}$ & $\begin{array}{c}\text { City hall } \\
\text { employee of } \\
\text { a city in the } \\
\text { interior of } \\
\text { São Paulo }\end{array}$ & Black \\
\hline Transsexual \\
Man
\end{tabular}

\section{Data collection and organization}

Data was collected between April 2017 and February 2018. The interviews, as a starting point for the collection of data in Oral History, were conducted through a script constructed with broad questions in order to cover the life history and the experiences of the collaborators in the health services. The triggering questions and guiding instructions were as follows: "Tell me a little about your life story"; "Tell me about your experiences at the UHS. How went?"; "How did you feel about the care provided by the health team?". In this context, the questions have the role of stimulating and allowing the collaborators to feel at ease in choosing the facts and impressions to be reported ${ }^{(13)}$. The combination of Oral Life History with Thematic Oral History was chosen for this study. It is possible to combine the two techniques in order to highlight some objective and essential data for the research without losing the richness present in the life narrative ${ }^{(11)}$.

Thus, in this research, specific questions about the experiences of employees in health services were highlighted. The first author, a graduate student in nursing at a public university, after receiving training, performed all the interviews. The collaborators were free to choose the location; however, the possibility was given to take place in a private room in the higher education institution to which the first author was linked during the collection period. Employees opted for this location, justified by the ease of access and the possibility of privacy; and chose the days and times according to their availability. The interviews were approximately 30 to 120 minutes in length, digitally recorded and transcribed in full.

The treatment of the content followed the steps proposed by the framework of Oral History, in which the transformation of recordings into written documents requires rigorous care and must pass through the stages of absolute transcription, textualization and, finally, transcreation. In the absolute transcription phase, all said words that were written in their raw state are preserved, without any kind of alteration; therefore, questions, agreement errors, repeated words and even the sounds emitted at the time of each speech were kept. In the second phase, the textualization, the questions asked by the interviewer, the sounds and noise were removed, and grammatical errors were corrected in order to make the text clearer and easier to read. In this phase, the "vital tone" was also chosen - a phrase taken from the interview itself - considered by the authors as a resource that determines the essence of that text and causes the interview to be reorganized based on the defined axis. The last phase is that of transcreation, when other elements are incorporated into the text in order to recreate the atmosphere of the interview and its context. A resource used for this was the field notebook, which is a space in which the interviewer recorded her impressions and experiences in relation to the interview environment and to the collaborators. The final versions of each interview were checked for accuracy and presented to collaborators to approve and authorize their use, since it is essential, from the perspective of Oral History, that they recognize themselves in the narratives ${ }^{(11)}$.

\section{Data analysis}

Oral History Interviews require the development of a balance between detailed analysis and maintaining the meaning of the participants' contributions ${ }^{(11)}$. In this study, specifically, a thematic analysis was carried out that sought to reveal not only the experience of the participants, but also the interpretations of the researchers. To guarantee the credibility of the analysis, the data was discussed with a second researcher to be validated. In addition, analytical decisions were recorded; and confirmation, ensured through the exercise of reflexivity and thematic coding.

\section{RESULTS}

When using the Oral Life History methodology, it is understood that the issues involved in the experiences of the people interviewed are essential for understanding the difficulties faced in health care. Reading the narratives allowed us to find many points of convergence, which were organized into themes that made the interface between life history and trajectories in viable health services. Each theme, in turn, was represented by the voice of the collaborators, who translate it in the most representative way. Finally, two themes were identified in the participants'stories: 1) gender and sexuality in their life stories; and 2) the trajectories in health services. Both are summarized in Figure 1 and are detailed below.

\section{Theme 1 - Gender and sexuality in life stories}

1.1 Subjectivities and sexuality:"They destroyed my subjectivities and shaped what they wanted me to be!"

Discovering yourself as trans translates into the lack of representativeness and visibility that carries with it anguish and feelings of not belonging to any group, an aspect that expands social isolation.

I have never been within any norms. And this generated a great depression and isolation, because I never fit in any group, I didn't fit in the gay group, I didn't fit in the lesbian group, I didn't fit in the cis group, I didn't fit in the straight group, I didn't fit in any group! None! Nobody wanted me, nobody wants me. (Erika) 


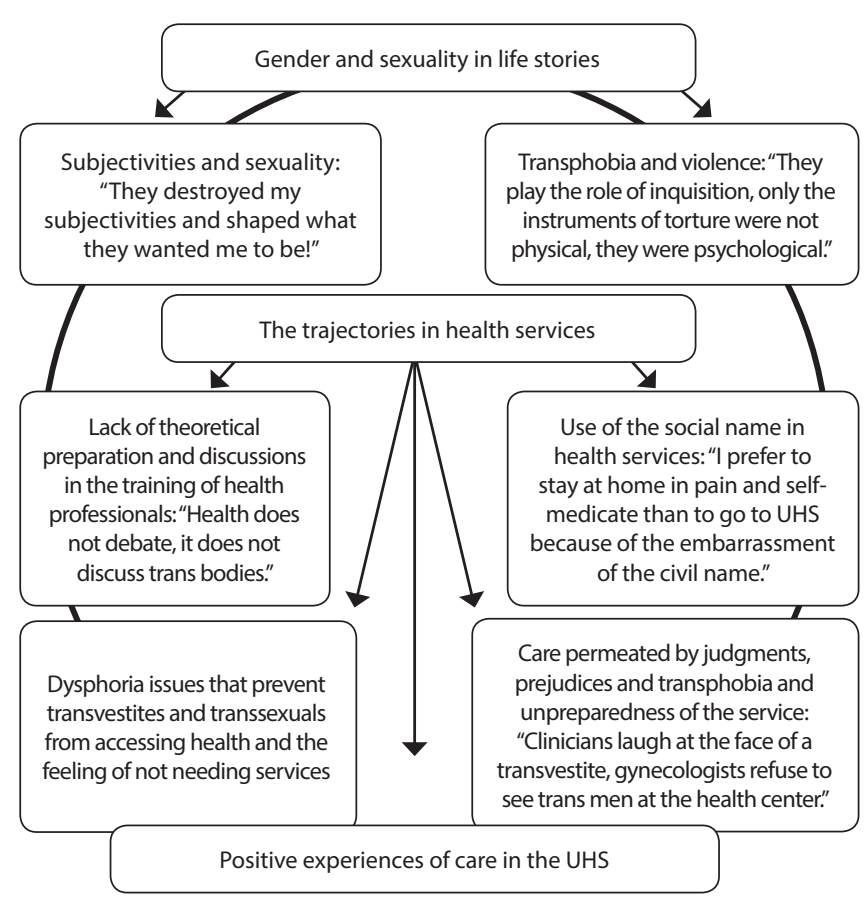

Figure 1 - Representative scheme of the themes found

Erika and Erick shared how oppressively their subjectivities were shaped and exploited by their families, even in their early teens.

They did my aesthetics, my psychological, my emotional, they destroyed my subjectivities and shaped what they wanted me to be! And they succeeded [...] I was just a teenage girl discovering herself, unable to be a girl, denying her entire existence, denying her subjectivities. (Erika)

So, I was getting more alone. Today, trying to rescue, I think it had to do with body change, but that, at that moment, I couldn't read that way, but I think it had to do with reading the world that started to see me more and more in a frame that I didn't fit, and it was very difficult to act, it was very difficult to exist, because it was always the framework that didn't give, that didn't fit. (Erick)

Erick brought difficulties experienced throughout his adolescent process, reporting the complexity of not recognizing himself by social standards and the need to build self-recognition without references:

There is also a physical issue, of looking at the entire body, while a trans person with only a few changes. It is complex because the images that are reproduced all the time by society are not of trans bodies, so you look and you have to be located sometimes, and that made me sure that the dysphoria is external. So, my reading of my body was a very empowering reading, like, I'm a man with a chest, with a vagina, with the uterus. (Erick)

In his narrative, Erick made several reflections on hegemonic masculinity and how dangerous it can be to pursue it, even if unconsciously:

I had this thing of rejecting the physique that didn't correspond, I didn't look in the mirror at all, until I was 16, I dreaded the mirror.
[...] It's funny, because looking in the mirror now means seeing me like this and being very comfortable, but at the same time, it is always feeling a certain weight. So much so that I have rethought aesthetic issues a lot, because it is always an image of hegemony, and an image of oppression, and an image of a white man. It is very ambiguous to have found me, but not knowing what to do with it now. Because being in that role and being read in this way allows you to start acting in very oppressive ways. And this is a trap that is difficult to understand even. (Erick)

1.2 Transphobia and violence: "They play the role of inquisition, only the instruments of torture were not physical, they were psychological."

Related to the theme presented above, the aspect that, perhaps, most affects the mental health of transsexual and transvestite people was identified: the transphobia or prejudice experienced daily by this population that has, at these moments, their existence repeatedly questioned.

I go through a process of crazy depression and then I develop anorexia, and then I start to think I'm a fat person, and look at this body! I was always skinny, and I started to think that I was fat and that being fat is a problem, and that I didn't need to eat that I couldn't eat, and I couldn't eat because I had nothing! I had to find a problem in my life, I had to find a distraction! [...] And I started to create a social phobia. People used to panic me, even today they do, actually. (Erika)

The experiences of childhood and adolescence also showed to be loaded with non-acceptance and violence.

And I go to the house of this aunt and uncle who are the contemporary inquisition, that's how I name them. They are inquisitors! They play the role of inquisition! We see the Spanish inquisition, the Portuguese inquisition that was exactly it, except that the instruments of torture were not physical, they were psychological, but that reached and led to depression and suicide. (Erika)

At 12 or 14 years old, I think it was the tensest time in my life, that I was plunged into a very strong depression. Because I didn't really go out, I couldn't interact with other people. (Erick)

In the narratives, it is possible to verify the influence of discrimination and marginalization in the most subjective aspects that will directly or indirectly reflect on the mental health of these people, often leading to eating disorders, severe depression and even suicide.

\section{Theme 2 - The trajectories in the services of the Unified Health System}

Based on the narratives presented in the previous theme, it was noted that there are specificities in the history of transsexual or transvestite people that are often unknown, ignored and neglected by health institutions and their professionals. Thus, this theme focuses on this issue in detail.

2.1 Lack of theoretical preparation and discussions in the training of health professionals: "Health does not debate, does not discuss trans bodies." 
The excerpts taken from the interviews endorsed evidence about the unpreparedness of health professionals to welcome and serve the trans population.

We feel that UHS needs training, from all employees, from doctors, from attendants, from the janitor to the surgeon. The lack of preparation, I think is the biggest difficulty; prejudice, we can dribble, but the lack of preparation is what bothers us most. I think that people, even in slightly larger positions as nurses, doctors leave college and do not have this preparation, this care to treat people with respect and in the way they want. I think the community agents are a little bit more prepared, a little more careful because they have to be in contact 24 hours with the public, so they have a little more handling with the Tquestion. (Gustavo)

The collaborators problematized the process of training these professionals, emphasizing that the discussion about gender and sexuality is still incipient or optional in health courses:

Health does not discuss gender and sexuality diversity. Health does not train its professionals and does not humanize its professionals to deal with differences, which is not even a difference, that I hate this word. It is nothing different! They are multiplicities! They are multiple! They are other forms. There are other anatomical and physiological configurations, which is different. (Erika)

2.2 Use of the social name in health services: "I prefer to stay at home in pain and self-medicate than to go to UHS, because of the embarrassment of the civil name."

The question of the social name also emerged in the reports; despite the right recognized by law, professionals still have difficulties to understand / implement this care and responsibility:

The doctor went to deliver my biopsy to the girl who was attending, and he called me her several times, and I wondered about his difficulty in understanding that he will have to tell people that I am a man, that he will have to defend that too, as a doctor! So, in order not to have a problem, it is easier to come with the biopsy of the uterus and say it is hers, because he doesn't have to explain it. (Erick)

2.3 Service permeated by judgments, prejudices and transphobia and unpreparedness of the service

In the narratives, there is a great stigma about transsexuals and transvestites, who are people immediately associated with sexually transmitted infections by health professionals.

But health care is not prepared. Then, you arrive at an appointment, and you are already dead, and you have to fight for the name, you have to fight for the right, you have to talk to the doctor and the doctor barely looks you in the face, the doctor is more concerned with your tests for HIV / AIDS, syphilis, gonorrhea, herpes and hepatitis than with your flu. (Erika)

In the following excerpts, there is evidence of the existence of professionals, generally doctors, such as gynecologists and endocrinologists, who refuse to attend transsexuals and transvestites.

It is a matter of name, it is a matter of the medical team, the nursing team, the technical team, the entire team not prepared to receive these people. Clinician laughs at the face of a transvestite, the endocrinologist refuses to see a transvestite at the health center, a gynecologist refuses to see a trans man at the health center. And this is real! We know it exists! With his legal rights to refuse, he can refuse to see a person if he gives any excuse, because no one will find out whether the transvestite's version is true or not. (Erika)

Another aggravating factor that compromises the attendance of this public is the total lack of knowledge and sensitivity of the professionals during consultations, sometimes ignoring the specificities of each individual, sometimes exotifying and pathologizing.

But in relation to medical monitoring, I tried to go to a gynecologist once, but the service was very dreadful, I was very scared, because she treated me like a sick person all the time, even pathologized. I went into the office and she already opened the CID and wrote there. And it was a terrible thing, he asked when I became a young girl! And she has worked with trans people for ten years. So, for me it was all very unforgivable. (Erick)

2.4 Dysphoria issues, difficulty accepting one's own body or part of it, which prevent transvestites and transsexuals from accessing health and the feeling of not needing services

In addition to all the issues that hinder or even prevent transsexuals and transvestites from accessing health services, there is still the issue of dysphoria. She, for some people, is very strong. However, in a cis-heteronormative system - one based on the socially constructed idea that existences considered normal are cisgender and heterosexuals and everything that escapes this rule becomes pathological -, it is a question never thought and continues to reinforce the removal of this population. In addition, another important point raised in the narrative is about the opening hours of health centers, which does not take into account the professionals who work at dawn, as was very well exemplified in the statements below:

The relationship is always this: laziness, ashamed of having to go in the morning, because the post does not work at night and they have a thing of not going out during the day because of the beard expression, because of having to put on makeup, for having to fix hair. You have to be in the UHS line at 6 am, and they worked until 5 am on the street, so they don't go because UHS is that time. They do not go because they will stand in line with mothers, with the elderly, with children, with everyone and everyone will look and it will be a joke. These are all issues that make access very difficult, and when they access, they are already very sick. (Erika)

I didn't know that I was a person, that I might have the right to demand something from the other. I thought that everything that came to me was what it had for me. I'm a transvestite! That's what I always say, I'm a transvestite! And this is a transvestite's life! They say that even today, this is a transvestite's life. (Erika)

The eminence of death: thought that was affirmed and exemplified by Erika's speech:

Transvestites are in a hurry, because life expectancy is so short, we need to live! I'm not going to spend three months waiting for care in a UHS queue, for a doctor or looking at my face. (Erika) 


\subsection{Positive experiences of care in UHS}

Despite all the difficulties presented and present in the care of transsexuals and transvestites by health services, some positive experiences were also reported. Many of them, linked to professionals sensitized and trained to attend.

So far, that was when I got really sick last year, and I went to the doctor, did the pap smear with the nurse, which was very good and I tell that to the boys. This is not the point, it is not the question of the exam, there is already a whole thing on top of that exam, there is a fear. I am 27 years old and it was the first time I went to do it. But the fact that I was treated like Erick all the time, was treated like I am, was quiet. I had no problem with exam, it was great. (Erick)

But those days ago that I had to go to the clinic, the woman asked for my social security number, which has the social name, took it there and typed it in and gave me the medical record. I kept looking, and she didn't put any civil names, she just put the social name. It was close to my neighborhood, it was wonderful. (Bianca)

A professional considered a reference in health care for transsexuals and transvestites is a psychologist, who was mentioned in three of the four interviews as the path to qualified care and as a promoter of essential emotional support in the process of transition from sex designated at birth to the gender that represents them. It offers support groups for transgender and transvestite men and women and ends up coordinating the health care of these people, referring them to specialized services.

Here in the city, there is an outpatient clinic, which is able to serve the T population, where the psychologist works, she attends people with all possible and imaginable problems and ends up that there are often no vacancies, but I think it is the only place that employees are prepared, because she is careful to talk to employees. (Gustavo)

It's just that we're lucky to have it; I think that if I didn't, it wouldn't be that good. She has always been an important part, because she is so incredible. She's like us, she takes our pain. And I think she's really amazing for that. (Bianca)

\section{DISCUSSION}

The objective of this study was to understand the life stories and itineraries of transvestites and transsexuals in health services. In this sense, experiences of violence and discrimination were seen as part of the participants' daily lives. With regard to the itinerary of this public in health services, it was evident the lack of preparation of professionals and services to meet their demands and needs. However, positive experiences in health services were also mentioned, signaling changes in the area.

It was noted that, despite the greater opening of gender expressions in recent years, there is still a subordinate binary definition, based on biological characteristics. Subjective markers are inscribed on the bodies; the marks of gender identity inscribed on bodies are closely linked to the historical, political and cultural context. Trans bodies put heteronormativity into play, seen as bodies that are inconsistent in relation to hegemonic social norms, which often causes social disgust ${ }^{(14)}$. These ideas have an impact on the lives of the participants and are materialized when they refer to situations of violence and discrimination. Based on the narratives, it was noticed that transphobia permeates the daily lives of this population in the most diverse environments of social coexistence ${ }^{(6)}$.

Researchers point out that transphobia, bullying and parental disapproval of gender expression are factors often associated with suicide attempts, which, according to "Dossier: Geography of Transgender Bodies", written by RedeTrans (Transnetwork), it is one of the main causes of death for transvestites and transsexuals, with the majority of cases occurring among females between 15 and 29 years old ${ }^{(15)}$. Even considering these alarming data, it is known that the data are underreported and research and debates on the subject are lacking ${ }^{(16)}$.

When the theme arrives in the field of health and, specifically, in services, aspects of the hegemonic discourse are clear and reflect the lack of knowledge about the specificities of the LGBTTQIA+ public, especially the population addressed in this study; this demonstrates the need for a national policy aimed at it, which should govern the assistance provided by professionals ${ }^{(17)}$. This lack of knowledge, often accompanied by lack of interest, as highlighted in the interviews, is reinforced during the training of the most diverse health professionals. This is because the theme is made invisible by teachers and students, for example, in Medicine, Psychology and Nursing courses, which end up sustaining and reinforcing the heteronormative and biologicist cis speeches, which compromise the assistance provided and remove transsexuals and transvestites from the health care ${ }^{(18)}$.

In the face of such reflections, it is essential that, during health training, there is a deepening of sexuality and gender identity, with a look beyond biological issues, seeking to encompass the social, cultural, affective and psychological spheres that permeate these experiences. It is necessary that the curricula of undergraduate and graduate courses in health follow and promote new approaches beyond cisgenerity and heteronormativity. It is also necessary that such discussions be carried out in an expanded way, traversing across disciplines such as mental health, reproductive health, obstetrics, men's health, women's health, children's health and the health of the elderly, in order to provide an understanding of how to gives in each stage the existence of these people, breaking with the silencing and the standards, responsible for the removal and mental illness of this public $^{(18)}$. On the other hand, managers and professionals who already work can use the data in this research to sensitize their teams about the difficulties already present in this population's life history, which should not be compounded by difficulties related to access to services and health care.

In addition to the lack of knowledge and ignorance in relation to the reality of this public and the existence of these bodies that escape the biological and hegemonic norm, prejudice, estrangement and repulsion on the part of health professionals in dealing with such bodies produce omission, indifference and negligence in the service to this public, interfering in the production of care. The situations in which the curious looks and permeated by judgment fall on the population portrayed and bring with them discriminatory attitudes, "jokes" in bad taste and other vexing situations are real in these people's daily lives and are reproduced in the health system by professionals ${ }^{(17)}$. 
In a survey conducted with transvestites from Santa Maria, Rio Grande do Sul, the interviewees reported that health services end up reproducing symbolic violence experienced socially and that, instead of promoting welcoming and comprehensive and equitable care, according to UHS principles, users are placed in mechanisms of pathologization and exclusion, always using cis-heteronormativity ${ }^{(19)}$. In addition to all these barriers and obstacles posed by professionals and services for the access of transsexuals and transvestites to health services, there is an immediate lifestyle typical of transvestites, who are always living with the possibility of death, which prevents them from making big future plans, and end up neglecting self-care and their health, becoming even more vulnerable ${ }^{(20)}$.

Another issue that appears quite strongly in the narratives is the disrespect to the social name in health services, being invariably placed as one of the main points for the removal of transsexuals and transvestites from the services. This, together with the episodes of discrimination and transphobia, corroborates the failure of this public to access health care. This aspect is placed as the initial barrier to access the system, since the discomfort of being called by a name that does not represent them and that still brings several memories and suffering prevents them from feeling safe and respected in that environment ${ }^{(21)}$. Decent service and respect for gender identity are the first step towards ensuring access for users and trans users is guaranteed, making health care possible ${ }^{(21)}$.

This discussion seems obvious, but even with the right to use the social name in all public agencies of the direct and indirect administration of the state of São Paulo (State Decree 55.588 / 2010), in most situations the disrespect to the identity of the users is linked to a total lack of knowledge of the existence and possibility of using the social name. It is, therefore, essential to have the training of professionals and an ostensive surveillance so that the rights of these people and their human condition are respected ${ }^{(3)}$.

\section{Study limitations}

Even taking into account the study's potential, it is worth noting that the results must be interpreted considering its two main limitations. First, the study design may have been influenced by the recall bias, present and documented in studies that use Oral History methods. Thus, other studies in the area of health are encouraged with different designs or strategies for collecting data on the experience of transsexuals or transvestites. The second limitation refers to the fact that the study explores the experiences and experiences of a small group, which may not reflect the reality of the population of which they are a part of. Linked to this, the perceptions of other informants, such as health professionals, were not examined, an aspect that can be investigated in future research.

\section{Contributions to the area of Nursing, Health or Public Policy}

The theme explored in this research is recent, and few studies have been published on how the area or health services have been dealing with paradigmatic changes related to gender issues. The findings indicate that health professionals, including nurses, were reticent or did not have adequate training to provide service/care to transsexuals and transvestites. In view of the privileged place that these professionals occupy in health services, they can act as protagonists in the care of these people and in the permanent education/training of other professionals. Understanding the life experiences of this population and how professional practice can walk in defense of life are contributions of this study.

\section{FINAL CONSIDERATIONS}

The Oral History of Life allowed us to enter and get to know the reality and experiences of transsexual and transvestite people in a broad way through their narratives. By going through their stories, told in a unique way by each employee, and listening to the voices often muffled and ignored by the cis-heteronormative society in which we live, it is possible to broaden the look at the health of this population based on their needs and real specificities, punctuated and analyzed by those who actually live this reality on a daily basis. The strength of this study lies in the identification of obstacles and obstacles faced by this public in the search for qualified and respectful health care. The results presented can illuminate the paths for professionals, teachers and students of health courses to seek to offer universal, comprehensive and equitable assistance in accordance with the principles of the Unified Health System.

\section{FUNDING}

Funding institution: FAPESP/Process: 17/00034-3

\section{AKNOWLEDGEMENTS}

We thank the participants who made this work possible.

\section{REFERENCES}

1. Arán M, Murta D, Lionço T. Transexualidade e saúde pública no Brasil. Ciênc Saúde Coletiva[Internet]. 2009 [cited 2019 Mar 20];14(4):1141-9. Available from: https://www.scielosp.org/pdf/csc/2009.v14n4/1141-1149/pt

2. World Health Organization (WHO). International Classification of Diseases: 11th Revision (ICD-11) [Internet]. 2018 [cited 20 Jan 2019 ]. Available from: https://www.who.int/classifications/icd/en/

3. Ministério da Saúde (BR). Secretaria de Gestão Estratégica e Participativa. Departamento de Apoio à Gestão Participativa Transexualidade e travestilidade na saúde [Internet]. 2015[cited 20 Jan 2019];1:194. Available from: http://bvsms.saude.gov.br/bvs/publicacoes/ transexualidade_travestilidade_saude.pdf

4. Pacheco RAS, Pacheco IS. Direito, violências e sexualidades: a transexualidade em um contexto de direitos. Estud Socio-Juríd. 2016;18(2):203-28. doi: 10.12804/esj18.02.2016.07 
5. Braga IF, Oliveira WA, Silva JL, Mello FCM, Silva MAI. Family violence against gay and lesbian adolescents and young people: a qualitative study. Rev Bras Enferm. 2018;71(Suppl-3):1220-7. doi: 10.1590/0034-7167-2017-0307

6. Snelgrove JW, Jasudavisius AM, Rowe BW, Head EM, Bauer GR. Completely out-at-sea with two-gender medicine: a qualitative analysis of physician-side barriers to providing healthcare for transgender patients. BMC Health Serv Res[Internet] 2012[cited 20 Jan 2019];12(110):113. Available from: http://www.ncbi.nlm.nih.gov/pmc/articles/PMC3464167/pdf/1472-6963-12-110.pdf

7. Santos ABD, Shimizu HE, Merchan-Hamann E. Processo de formação das representações sociais sobre transexualidade dos profissionais de saúde: possíveis caminhos para superação do preconceito. Ciênc Saúde Colet. 2014;19(11):4545-54. doi: 10.1590/1413-812320141911.15702013

8. Lionço T. Atenção integral à saúde e diversidade sexual no Processo Transexualizador do SUS: avanços, impasses, desafios. Physis (Rio J.) [Internet]. 2009[cited 21 Jan 2019];19(1):43-63. Available from: http://pesquisa.bvsalud.org/portal/resource/pt/lil-525975

9. Sampaio LLP, Coelho MTAD. Transexualidade: aspectos psicológicos e novas demandas ao setor saúde. Interface Comun Saúde Educ. 2012;16(42):637-49. doi: 10.1590/S1414-32832012000300005

10. Cardoso MR, Ferro FL. Saúde e População LGBT: demandas e especificidades em Questão. Psicol Ciênc Prof. 2012;32(3):552-63. doi: 10.1590/ S1414-98932012000300003

11. Meihy JCS, Holanda F. História oral: como fazer como pensar. São Paulo: Contexto; 2007.

12. Instituto Brasileiro de Geografia e Estatística (IBGE). População estimada em 2010, São Carlos, São Paulo [Internet]. 2010 [cited 20 Jan 2018$].$ Available from: https://cidades.ibge.gov.br/brasil/sp/sao-carlos/panorama

13. Meihy JCSB, Ribeiro SLS. Guia Prático de História Oral: para empresas, universidades, comunidades, famílias. São Paulo: Contexto; 2011.

14. Longaray DA, Ribeiro PRC. Travestis e transexuais: corpos (trans) formados e produção da feminilidade. Rev Estud Fem. 2016;24(3):761-84. doi: 10.1590/1806-9584-2016v24n3p761

15. Nogueira SNB, Aquino TA, Cabral EA. Dossiê: a geografia dos corpos das pessoas trans. Rede Trans Brasil [Internet]. 2017 [cited 2019 Jan 15]. Available from: http://redetransbrasil.org.br/arquivo-do-monitoramento/a-geografia-dos-corpos-trans/

16. Bauer GR, Scheim Al, Pyne J, Travers R, Hammond R. Intervenable factors associated with suicide risk in transgender persons: a respondent driven sampling study in Ontario, Canada. BMC Public Health. 2015;15:525. doi: 10.1186/s12889-015-1867-2

17. Duarte MJO. Diversidade sexual, políticas públicas e direitos humanos: saúde e cidadania LGBT em cena. Temporalis[Internet] 2014 [cited 2019 Jan 20];1(27):77-98. Available from: http://portaldepublicacoes.ufes.br/temporalis/article/view/7209

18. Guimarães RS, Vergueiro V, Marcos MA, Fortunato I. (Org.). Gênero e cultura: perspectivas formativas. Vol. 2. São Paulo: Edições Hipótese; 2018.

19. Souza MH, Malvasi P, Signorelli MC, Pereira PP. Violence and social distress among transgender persons in Santa Maria, Rio Grande do Sul State, Brazil. Cad Saúde Pública. 2015;31(4):767-76. doi: 10.1590/0102311X00077514

20. Associação Nacional de Travestis e Transexuais (ANTRA). Mapa dos assassinatos de Travestis e Transexuais no Brasil em 2017 [Internet]. Brasília: (ANTRA); 2018 [cited 2019 Mar 15]. 121 p. Available from: https://antrabrasil.files.wordpress.com/2018/02/relatc3b3rio-mapa-dos-assassinatos2017-antra.pdf

21. Rocon PC, Rodrigues A, Zamboni J, Pedrini MD. Difficulties experienced by trans people in accessing the Unified Health System. Ciênc Saúde Colet. 2016;21(8):2517-26. doi: 10.1590/1413-81232015218.14362015. 